\title{
Growth Prospects and Customer Expectations in Islamic Banking
}

\author{
Saqib Muneer, Muhammad Shahid Tufail, Ahsan Zubair \\ Government College University, Faisalabad, Pakistan \\ Saqibmuneer85@gmail.com
}

\begin{abstract}
Islamic Banking has gained enormous popularity in Pakistan in a short span of time and still has a huge potential to grow in the market. Many Conventional Banks having Islamic Banking windows and a few fullfledged Islamic banks are striving hard to remain alive in the stiff competition for market share, resulting in more banking choices for the customers. Still there is lot to be achieved and the whole banking system has to get rid of the curse in the form of Riba, which has strongly been denounced and prohibited in the Holy Quran. Islamic Banks at the moment hold merely $9.4 \%$ of the whole banking Market which is far below than desired. In this study, an attempt will be made to analyze the growth trends in the Islamic banking and its implications for the society and the economy in particular. Customers' perceptions \& expectations and certain myths regarding Islamic banking will also be captured during the study. This will not only help us in understanding the potential and opportunities available in the industry but also give an idea that what the customers want and expect from Islamic banking. Moreover, the study will also add to the latest pool of knowledge on the subject. There seems a dearth of updated quality research on the matter and this will serve as an important reference and latest work on Islamic Banking in Pakistan.
\end{abstract}

Keywords: Islamic Banking, Growth Trends, Customer Expectations, Conventional banking

\section{Introduction}

Islamic Banking in Pakistan was formally introduced way back in 2001 when the government chose to support Islamic banking in a steady approach and function parallel and well-suited system that is in line with international best practices. As a result, Meezan Bank Limited (MBL), the first Islamic Bank of the country started its operations during March, 2002. Since then the industry has been constantly performing with remarkable growth, outshining the growth rates witnessed by the conventional banks in the last few years. Having large majority of religiously conservative people, the ever growing Islamic Banking industry of Pakistan offers ample opportunities to a reasonably large segment of the public which are unbanked yet. As a result there shall be financial soundness in the country and hence the industry will play a role in achieving overall national economic objective, i.e. expansion of financial sector. State bank of Pakistan has also established the Islamic banking framework to make sure sound, stable, transparent and flexible legislation for Islamic Banks.

Islamic Banking Industry Overview: The Islamic Banking Industry kept growing and reaching new markets and developing innovative products to the customers according to their needs. As of September 2014, a total of 22 banks with 1423 Branches spread across the country were involved in Islamic Banking practices with an asset base of PKR 1,102 billion. Islamic banking assets and deposits have captured a market share of 9.9 percent and 10.7 percent respectively by end September 2014.

Islamic Banking Branch Network Analysis: Islamic Banking Industry (IBI) branch network has grown tremendously over the years and in a very short span of time it has added more than 1423 branches. By analysis of the distribution of branch network of IBI, we can see that the network is heavily concentrated in two provinces i.e. Punjab and Sindh as both these provinces account for nearly 78 percent branches of overall Islamic Banking Industry (IBI) branch network.

In Pakistan there are 5 fully specialized Islamic Banks having a branch network of 838 branches as of September 2014. 17 Conventional Banks have 488 Islamic Branches spread over all the country. Apart from this, different banks have 97 Islamic sub Branches are operating in the market catering to thousands of customers. Following is the list of All Islamic Branches in the country. 
Table: 1 Province Wise Additional Branches as of September 2014

\begin{tabular}{lll}
\hline Province & Total Number & Share (percent) \\
Punjab & 634 & 44.6 \\
Sindh & 476 & 33.5 \\
Khyber Pakhtoonkhawa & 152 & 10.7 \\
Baluchistan & 59 & 4.1 \\
Gilgit Baltistan & 5 & 0.4 \\
FATA & 4 & 0.3 \\
Federal Capital & 78 & 5.5 \\
AJK & 15 & 1.1 \\
Total & 1423 & 100 \\
\hline
\end{tabular}

\section{Literature Review}

No one can deny the importance of the Banking industry in making funds available to industries and contributing towards economic and financial growth and stability. A deep-rooted and sound banking industry has the ability to with stand economic down turns in the economy and plays an important role in the development of the country (Aburime, 2009). In Pakistan too, banking sector has evolved as a strong industry over the years and become the backbone of the fragile but resilient economy, although initially at the time of independence it faced tremendous challenges like acute scarcity of resources and uncertainty due to prevailing political and socioeconomic conditions but today it stands out as one of the best performing sector having deposit base of more than 7,195,817 Million Rupees with 38 banks (Local \& Foreign) over 10,361 branches spread all over the country. (Financial Stability Review 2013) Pakistan started making serious efforts for Islamic Banking in 1970s when an article 38 (f) was included in the Constitution of 1973 which holds the State responsible for eliminating "Riba as soon as possible" (Memon, 2007).

However, a major step was taken in the early 80s to adapt the banking system according to the tenants of Islamic principles. Various legislations were modified to accommodate non-interest based transactions and for doing this the relevant authorities and the banking system were allowed definite timeline to transform the conventional banking sector into Islamic one. But during early nineties, some of the decisions and exercise was challenge in the Federal Shariat Court which declared some products and processes being used by the banking system un-Islamic (Saeed, 2011). After reviewing the flaws and rectifying the objections raised by the honorable court, State Bank of Pakistan issued new guidelines for setting up of Islamic banks in late 2001. As a result the first license for Islamic Banking was issued to Meezan Bank Limited was allowed to function as a full-fledged Islamic bank in January, 2002.

In this study, an attempt has been made to analyze the growth trends in the Islamic banking and its implications for the society and the economy in particular. Customers' perceptions \& expectation and certain myths regarding Islamic banking have also been captured during the study. This will help us in understanding the potential and opportunities available in the industry but will give an idea what the customers want and expect from Islamic banking. Moreover, the study has added to the latest pool of knowledge on the subject. During the study it was revealed that there is a dearth of updated quality research on the matter and this will serve as an important reference and latest work on Islamic Banking in Pakistan. After the commencement of Islamic banking in the country, we have seen great promotion and advocacy of Islamic banking services and many Banks jumped into this business. Today, there is a huge potential for further growth and thus the potential for Islamic banking services should be harnessed as quickly as possible through active education drives for the population and training of bank staff. The research project has highlighted the current trend of rapid growth of Islamic banking sector in Pakistan and its impacts on the development of a Riba Free economy. Customers' perceptions and certain myths regarding Islamic banking have also been captured during the study. This will not only help us in understanding the potential and opportunities available in the industry but will give an idea what the customers want and expect from Islamic banking. Moreover, the study will also add to the latest pool of 
knowledge on the subject. There seems a dearth of updated quality research on the matter and this will serve as an important reference and latest work on Islamic Banking in Pakistan

\section{History and Evolution of Islamic Banking System}

International Perspective: It is believed that the first ever Islamic banking was established in Egypt without directly using the Islamic concept. Ahmad El Najjar of Egypt was the founder and pioneer of a saving bank in a small town of Mit Ghamr in 1963 which was based on profit sharing. There after many such banks were established across the country and by the end of 1967 there were 9 such banks in Egypt (Ahmad, 2010). These banks were basically not commercial entities but were in fact saving-investment institutions. Later on, a fully Interest-free commercial bank named Nasir Social Bank was founded in Egypt without any reference to Islam or Shari'ah (Hayat, 1993). In the 1970s, as the political scenario was changed over Islamic World, Islamic Banks and financial institutions were no more hiding their identity like those of Egyptian banks. Scores of Islamic Banking Institutions were established across Middle East catering to the needs of the customers and Islamic Bank thus flourished in many Islamic states like Bahrain, UAE, Egypt, and Sudan over the years (Ahmad, 2010). Islamic Banks were not only confined to Islamic Countries but some countries like Philippines started promoting Interest free banking without direct reference to Islamic Shariah. The Philippines Amanah Bank (PAB) founded in 1973, was completely not an Islamic bank but efforts are underway to convert the PAB into a full-fledged Islamic bank (Iqbal, 2010; Makiyan, 2010). In South east Malaysia was the first country to introduce Islamic banking in 1983. Although Earlier, Muslim Pilgrims Savings Corporation (MPSC) was established in 1963 with the sole purpose to motivate people to save for performing Islamic Haj. MPSC was later merged into the Pilgrims Management and Fund Board in 1969, which is now popularly known as the Tabung Haji. Late on, Bank Islam Malaysia Berhad (BIMB), a full-fledged Islamic Bank was set up in 1983 inspiring from the success of Tabung Haji (Hayat, 1993 and BIMB).

In December 1973 The Organization of Islamic Countries (OIC), established Islamic Development Bank with an objective to promote economic \& social development of member countries and Muslim communities separately or jointly in accordance with the principles of Shari'ah. The Islamic Development Bank offers not only financial services against certain fees but also gives financial aid on profit-sharing bases to its member countries (Source: IDB). Interestingly, Islamic banking concept has impressed some non-Muslim Countries too. During seventies, there were interest free savings and loan societies established in some localities (Ahmad, 2010). In Europe, the first ever The Islamic Banking institution was established in Luxembourg in 1978. Later on, Islamic Bank International (IBI) and the Islamic Investment Company (IIC) have been established in Copenhagen, Denmark and Melbourne, Australia respectively (Hayat, 1993). In the late 20th century, a number of Islamic banks were created, to cater to this particular banking market. In short, from a modest commencement from a small village in Egypt in the early 60s, Islamic Banking has now spread across the globe and has been recognized as a genuine alternative the conventional banking system. In a very short span of time, it has established strong foothold all over the world. There is a great potential for Islamic Banking to grow stronger and dominate the financial world very soon.

Pakistan's Perspective: Pakistan has witnessed sharp growth in Islamic Banking and its popularity is growing day by day. In Pakistan, during 1970s, some serious efforts started towards Islamisation of the financial system. In the constitution of 1973 an article was included in which state was held responsible for making efforts for elimination of Riba from the country. But practical and comprehensive initiatives were undertaken during 1980s when different legislations like State Bank Act of 1956, The Banking Companies Ordinance 1962, Negotiable Instruments Act of 1882 \& Recovery of Loans Laws were amended to make them according to Islamic Principles. Pakistan is among one of the few first countries in the world to have started non-interest based banking. The advisory committee established under the Constitution of 1973, The Council of Islamic Ideology (CII) also reviewed certain laws and submitted its report in 1980 in which recommendations were made to replace the interest based banking system with a PLS Based banking system. In another recommendation, Government was asked to set up interest-free 'common pool of funds' on cooperative basis to replace the existing interest bearing government securities (Sheikh et al., 2010). As a result, Participation Term Certificate (PTC) for commercial Financing was launched which was later swapped with Term Finance Certificate. Later on, many more non-interest based products were introduced. Conventional Banks started to adopt the Islamic Banking steadily, and undertook certain steps like opening separate interest free counters at the branches. Banks developed certain products like Musharika in 1982 for their customers who required funds for meeting working 
capital needs of trade and industry. But Banks formally launched their PLS Products in April, 1985 (Saeed, 2011).

The SBP primarily took far-reaching decisions for the implementation and development) of financial instruments based on Islamic ideology. But this pace could not be continued throughout due to certain reasons and the whole process came to a standstill. In 1991, The Government of Pakistan established the Federal Shariat Court which ordered banks especially the State Bank to remove interest based transactions by the end of 2001 . This was a big decisions and a challenge to the banks because it was not possible to act on the order in such a short period of time. Since 2002 in Pakistan Islamic Banks have witnessed stiff competition among themselves and as well as from conventional banks. The Government has not only allowed Conventional and Islamic banking to operate in parallel but conventional banks can offer Islamic banking services through dedicated Islamic windows. Subsequently, Today in Pakistan we have 5 dedicated Islamic Banks working with a branch network of 838 branches as of September 2014. Moreover, 17 Conventional Banks have 488 Islamic Branches spread over all the country. Apart from this, 97 Islamic sub Branches of different banks are operating in the market catering to hundreds of thousands of customers. They are competing in a highly competitive environment for the provision of quality services according to customers' expectations (Nassir-Shaari et al., 2011).

In addition to banking institutions, several Islamic Finance instruments like Islamic Mutual Funds, Takaful Companies, Mudaraba Companies etc have been serving Islamic Customers. And recently Government has been serious in creating an Islamic Sukuk (bond) market. However, it is concluded that although Islamic banking growth has performed at a very rapid pace but when compared with conventional banks, the growth of Islamic banks lacks a mile behind that of conventional banks. Figures reveal that Assets of the Islamic banking industry have reached to Rs. 1,102 billion in September 2014. Similarly deposits of the Islamic banking industry witnessed growth over the years and were recorded as Rs 934 billion. Total Islaminking Assets and deposits have managed to capture an overall market share of $9.9 \%$ and $10.7 \%$ respectively by the end of September 2014 . Profitability of the Islamic banking industry has also witnessed an increase reaching to Rs 9.4 billion, substantially higher than Rs 5.6 billion profit earned by Islamic banking industry by the end September 2013. However, its shares in terms of asset percentage of banking industry were just $3.2 \%$ while comparing conventional banking assets (IBB, SBP- September 2014).

\section{Methodology}

For this study, we have extensively relied on both primary as well as secondary data. The primary data is basically used to determine the growth of Islamic Banking in Pakistan. We have studied the growth trend in market share, asset size, investment and profitability of Islamic Banks in the country over years and have produced them here in the form of tables and charts. Secondary data was collected from different sources. State Bank of Pakistan has Islamic Banking Department which provides useful information about Islamic Banking in the country. We thoroughly visited the website and found useful and high quality data on the subject. State Bank of Pakistan publishes a quarterly Islamic Banking Bulletin where lot of analysis is done regarding different parameters. We have also consulted the project "KAP Study" undertaken and published by State bank of Pakistan along with an International Development Agency. Besides this, a large number of websites including those of some Islamic Banks, different journals, and research studies were consulted to gather the secondary data for this study. To understand customer satisfaction and perception regarding the quality of service and operations of the Islamic Banks, Primary data was collected through a structured questionnaire. As mentioned earlier there are five full-fledged Islamic banks and Seventeen (17) Conventional banks offering Islamic Banking services with over 1400 branches across the country. It was not possible to cover all of them. So, as sample customers of three branches of Islamic banks i.e. Meezan Bank Ltd, Raast Banking (Islamic Banking Group) of the Bank of Khyber and Bank Alfalah Islamic situated in Peshawar Cantt were selected for the customers of Islamic Banks. For Conventional Banks, Branches of Soneri Bank, Habib Bank Ltd and the Bank of Khyber were selected at convenience. A sample of 100 questionnaires was distributed equally through the branch officers who were kind enough to help in getting the forms filled from their respective customers. The overall findings and their interpretations are presented in Table 3.

Growth of Islamic Banks in Pakistan: After the establishment of Meezan Bank Limited in 2002 as the first fullfledged Islamic Bank, Pakistan has witnessed a tremendous growth in Islamic Banks in Pakistan. Presently, 5 
fulls- fledged Islamic Banks and 17 conventional banks have opened more than 1423 branches across the country. I have collected data for the last 12 years about Total Assets, Net Investments, Total Deposits and number of Branches of the Islamic Banking Industry and analyzed the growth trends of these parameters.

Total Assets: Total Assets of the Islamic banks have grown exponentially over the years. In 2002 Total Assets of the Industry were just 7 billion Rupees which have now reached Rs. 1,102 Billion as of September 30, 2014. In the beginning the growth was steady but increased sharply after 2009 when many banks started Islamic Banking operations. The market share of total assets of Islamic banks in overall banking industry increased to 10.7 percent by end September 2014.

Total Deposits: Many New Islamic banks entered the market and successfully mobilized huge deposits over the years and captured a market share of $10.7 \%$ as of September 30, 2014. The total assets stand at 934 Billion Rupees at the end of the third quarter of 2014. The market share of total deposits of Islamic banks in overall banking industry increased to 9.9 percent by end September 2014.

Net Financing and Investments: Financing and Investments are the major source of revenue for the banks and therefore it is imperative for the banks to lend money prudently and invest in safe places to ensure maximum return for the shareholders. In this regards as we can see from the figure below that Islamic Banks have increased their investments substantially over the years and posted an upward trend. Net Investments of the bank had reached their peak in 2013 but the figures have declined due to economic slowdown during 2014.

Branch Network and Islamic Banking Institutions: Islamic Banks grew sharply during the initial years but steadied after 2007. Some banks were merged or acquired thereby numbers fluctuated between 18, 19 and later on declined to 17 in 2011. But recently new conventional banks have entered the market causing the number to rise to 22 at the end of September 2014.

Table 2: Total Islamic Banking Institutions and total number of Islamic Branches.

\begin{tabular}{|c|c|c|c|c|c|c|c|c|c|c|c|c|c|}
\hline GrowthinlslamicBanking & 2002 & 2003 & 2004 & 2005 & 2006 & 2007 & 2008 & 2009 & 2010 & 2011 & 2012 & 2013 & 2014 \\
\hline TitalAssets & 7 & 13 & 44 & 71 & 119 & 206 & 276 & 366 & 476 & 641 & 837 & 1014 & 1102 \\
\hline Deposits & 5 & 10 & 30 & 48 & 73 & 138 & 186 & 226 & 338 & 475 & 626 & 709 & 934 \\
\hline NetFinancing\&Investment & 5 & 8 & 30 & 50 & 84 & 147 & 202 & 282 & 392 & 522 & 706 & 868 & 693 \\
\hline $\begin{array}{l}\text { Totallslamic Banking } \\
\text { Institutions }\end{array}$ & 1 & 4 & 9 & 11 & 14 & 18 & 18 & 19 & 18 & 17 & 18 & 19 & 22 \\
\hline T'totalNo, of Branches & & 17 & 48 & 70 & 150 & 289 & 311 & 611 & 720 & 882 & 1097 & 1304 & 1423 \\
\hline
\end{tabular}

\section{Results}

A set of sixteen questions was developed in the form of questionnaire which was distributed among one hundred customers of three Islamic Banking Branches and three Conventional banking branches. Among them 50 customers of Islamic Banks were requested to fill out the forms and another 50 customers of conventional banks completed the questionnaire. Following are the findings of the research.

Reputation of Islamic Banks: Following Figure indicates that 56\% of respondents at Islamic Banks agreed that Islamic Banks are more reputable than conventional banks as compared to $14 \%$ respondents at Conventional Banks who were in agreement. While $26 \%$ \& $40 \%$ were neutral to the question in cases of Islamic \& Conventional Banks respectively. $46 \%$ of the respondents at Conventional Banks did not agree about the notion that Islamic Banks were more reputable than Conventional Banks.

Quality of Service: $48 \%$ of the respondents thought that Islamic Banks were providing better services than conventional banks while 38\% were unclear about it. In case of Conventional Customers only 34\% were agreed that Islamic Banks have better quality of service than 
Conventional banks while $46 \%$ disagreed.

Favorable Prices of Islamic Banks: Majority of both Islamic and Conventional bank customers were indifferent about the favorability of prices of Islamic Banks as $40 \%$ and $48 \%$ of the respondents at Islamic and Conventional Banks remained neutral about the pricing of Islamic Products respectively. Only 38\% of customers at Islamic Banks deemed their prices favorable as compared to $12 \%$ at conventional Banks. While $22 \%$ at Islamic Banks and $40 \%$ at conventional Branches thought that Prices of Islamic Bank Products were not favorable.

Solution to personal business needs: $50 \%$ of the respondents at Islamic Banks agreed that Islamic Banks offer solutions to personal/business needs of the customers as compared to merely $8 \%$ of the respondents at Conventional banks. While $26 \%$ of the customers of Islamic banks and $50 \%$ of the customers of conventional banks remained neutral about this particular question.

True Shariah Compliant Banking Products: $66 \%$ of the customers of Islamic banks thought that Islamic Banks offer truly Shariah Compliant Islamic Banking Products to their customers as compared to only $10 \%$ of the customers of Conventional bank customers. It is worth mentioning here that about $90 \%$ of customers of the Conventional Banks either remained neutral or disagreed with the notion that Products of Islamic Banks were Truly Shariah Compliant.

Religious Satisfaction and Comfort in doing Business with Islamic banks: An overwhelming majority of customers i.e. $74 \%$ of the respondents at Islamic banks felt religious satisfaction and comfortable in doing business with Islamic Banks. While 58\% of the respondents of the Conventional Banks remained undecided in this regards and $34 \%$ of them disagreed with this notion.

Choice of Selection of the Branch: Customers were asked about the choice for bank selection on the basis of convenience of location instead of other facilities offered and as a result $32 \%$ of the respondents at Islamic Banks agreed and another 32\% disagreed that their selection of branch was based on convenience of location. But $62 \%$ of the conventional bank customers agreed that they chose Banks based on the convenience of location instead of other facilities offered.

Contribution of Islamic Banks in Societal Balance, Human Prosperity and Welfare: Only $26 \%$ of the respondents at Islamic banks and 18\% at the Conventional Banks agreed that Islamic Banks contribute to the societal balance, Human prosperity and welfare. While majority of the customers at both Islamic and Conventional Banks either disagreed or remained neutral in this regards.

Islamic Banks as a Complete Alternative Banking System: $62 \%$ of the Islamic Bank customers deemed that Islamic Banks served as a complete alternative banking system in the country while $38 \%$ of the respondents of conventional banks disagreed with this notion. While $42 \%$ decided to remain neutral in this regards.

Willingness to pay more for Islamic Products: Only 32\% of the respondents at Islamic Banks were willing to pay more for Islamic products because they are Shariah Compliant while only $2 \%$ of the conventional bank customers were willing to pay more. $70 \%$ of the conventional and $32 \%$ of the Islamic bank customers was not willing to pay more for Islamic Products.

Table 3: Tabular Representation of Results

\begin{tabular}{llllll}
\hline & & $\begin{array}{l}\text { Islamic } \\
\text { Customers }\end{array}$ & $\begin{array}{l}\text { \%age of Islamic } \\
\text { Customers }\end{array}$ & $\begin{array}{l}\text { Conventional } \\
\text { Customers }\end{array}$ & $\begin{array}{l}\text { Conventional } \\
\text { Customers }\end{array}$ \\
\hline Age group (Years) & $18-30$ & 17 & $34 \%$ & 9 & $18 \%$ \\
& $31-40$ & 13 & $26 \%$ & 11 & $22 \%$ \\
& $41-50$ & 10 & $20 \%$ & 15 & $30 \%$ \\
& $51-60$ & 8 & $16 \%$ & 9 & $18 \%$ \\
Gender & 61 and above & 2 & $4 \%$ & 6 & $12 \%$ \\
& & & & & $76 \%$ \\
Educational Qualification & Male & 39 & $78 \%$ & 38 & $24 \%$ \\
\hline
\end{tabular}


Monthly Income (Rs)

Purpose of opening of Bank Account

$\begin{array}{lc}\text { Primary } & 2 \\ \text { High School } & 8 \\ \text { Intermediate } & 12 \\ \text { Graduate } & 21 \\ \quad \text { Graduate } & \& \\ \text { Higher } & 7\end{array}$

Less than 20,0004

$20,001-40,000 \quad 19$

$40,001-60,000 \quad 18$

$60,001-80,000 \quad 6$

80,001

and3

Salary Account 24

Saving 11

Business 11

Online

Transaction 4

Others

Understanding the key concepts of Islamic Banking

Yes

No

$4 \%$

$16 \%$

$24 \%$

$42 \%$

$14 \%$

$8 \%$

$38 \%$

$36 \%$

$12 \%$

$6 \%$

$48 \%$

$22 \%$

$22 \%$

$8 \%$

$0 \%$

$68 \%$

$32 \%$

$56 \%$

$26 \%$

$18 \%$

Islamic Bank provides better

Services than Conventional Bank

Prices of Islamic Products are more

$\begin{array}{ll}\text { Agree } & 28 \\ \text { Neutral } & 13 \\ \text { Disagree } & 9\end{array}$

$\begin{array}{ll}\text { Agree } & 24 \\ \text { Neutral } & 15 \\ \text { Disagree } & 11\end{array}$

favorable than Conventional Bank

Products.

Islamic Banks offer solutions to

$\begin{array}{ll}\text { Agree } & 19 \\ \text { Neutral } & 20 \\ \text { Disagree } & 11\end{array}$

Personal/business needs of the customers.

Islamic Banks offer truly Shariah Compliant Islamic Banking Products

$$
\text { Ag }
$$

Agree 25

Neutral 13

12

$8 \%$

Disagree

$\begin{array}{ll}24 & 48 \% \\ 20 & 40 \%\end{array}$

$\begin{array}{ll}\text { Agree } & 33 \\ \text { Neutral } & 12 \\ \text { Disagree } & 5\end{array}$

$23 \quad 46 \%$

One feels religious satisfaction and comfortable in doing business with Islamic Banks.

Agree

Neutral
$14 \%$

$40 \%$

$46 \%$

$34 \%$

$30 \%$

$36 \%$ 


$\begin{array}{lllll}\text { Disagree } & 3 & 6 \% & 17 & 34 \%\end{array}$

Your choice for bank selection is based on convenience of Location of instead of other facilities offered

Islamic Banks can contribute more

Agree
Neutral
Disagree
16

to the societal balance, human prosperity and welfare.

Islamic Banks serve as a complete

$\begin{array}{ll}\text { Agree } & 13 \\ \text { Neutral } & 19 \\ \text { Disagree } & 18\end{array}$
alternative banking system in the country.

$\begin{array}{lllll}\text { Agree } & 31 & 62 \% & 10 & 20 \% \\ \text { Neutral } & 12 & 24 \% & 21 & 42 \% \\ \text { Disagree } & 7 & 14 \% & 19 & 38 \%\end{array}$

I am willing to pay more for Islamic product because they are Shari'a Compliant

$\begin{array}{lll}32 \% & 31 & 62 \% \\ 36 \% & 12 & 24 \% \\ 32 \% & 7 & 14 \%\end{array}$

$\begin{array}{lll}26 \% & 9 & 18 \% \\ 38 \% & 18 & 36 \% \\ 36 \% & 23 & 46 \%\end{array}$

\begin{tabular}{lllll} 
Agree & 16 & $32 \%$ & 1 & $2 \%$ \\
Neutral & 18 & $36 \%$ & 14 & $28 \%$ \\
Disagree & 16 & $32 \%$ & 35 & $70 \%$ \\
\hline
\end{tabular}

\section{Conclusion}

As evident from the findings, the recent expansion of Islamic Banking in the Country has been extremely successful and the credit for this success goes to all the stakeholders i.e. The Government, SBP, and Private Sector. SBP's multi-pronged strategy for development of Islamic Banking in the country has been very effective and bore fruits. The recent growth in Islamic Banking has been remarkable by all standards. Islamic banks have been able to achieve a market share of more than $10 \%$ in about 12 years in such a competitive banking sector which is truly an outstanding achievement. The re-launch incident has been very useful and provides as a strong foundation on which the strategy has been put in place. The research findings also reveal that Islamic banking clients are more satisfied, well informed and consider Islamic banks as their first choice. Still lot has to be done and more customers need to attract towards Islamic banking by offering new innovative products and alternative solutions to the needs of the customers. Customers of Conventional Banks were indifferent to Islamic Banking and their perceptions should be changed.

Recommendations: This entire debate clearly states that Islamic Banking has grown decently as compared to the Conventional Banking system in Pakistan over the past few years, and according to SBP, Islamic Banking has great potential to grow further in coming years. Following are a few recommendations for the betterment of the industry. The Banks need to give special attention to the awareness among the people, people should be educated about the operation and significance of Islamic Banking concept because many people in Pakistan and all around the world think that Islamic Banking is just a delusion and that there is actually no difference between Conventional and Islamic banks and that the only difference is in the name. Due to phenomenal growth and expansion of Islamic Banking in the country, one must ensure there is adequately skilled human resource available in the market. Islamic Banks and specially State Bank of Pakistan and Institute of Bankers, Pakistan (IBP) need to play their due role in imparting and arranging extensive training programs for the workforce so that in times of high demand adequate resources are available to be employed

Branch Network should grow and reach out to those non-banked areas (especially the rural areas) and capture more and more of the market share. Islamic Banks usually are left with very few options when it comes to invest in Shariah Compliant instruments. Resultantly they end up investing in Government Securities and Shares which affects the spirit of Islamic Banking Concepts. Sukuk Bonds etc should be introduced in the market 
as soon as possible. Islamic Bank should launch several competitive financial products so that they can easily compete with the products of conventional banking and that can attract the new customers for the Islamic Bank. Recently Islamic Banking industry mainly depends on KIBOR which is not Islamic in any ways but still we have not been able to establish exclusive Bench Mark. Scholars in Islamic banking should research and come up with an alternative to this KIBOR. More Research is required to develop new products and for better understanding of the market

\section{References}

Aburime, U. T. (2009). Impact of Political Affiliation on Bank Profitability in Nigeria. African Journal of Accounting, Economics, Finance and Banking Research, 4(4).

Ahmad, A. (2010). An empirical investigation of Islamic banking in Pakistan based on perception of service quality. African Journal of Business Management, 4(6), 1185-1193. Retrieved from http://www.academicjournals.org/AJBM

Hayat, N. (1993). Theory \& Practice of Islamic Banking in Pakistan. Lahore: Department of Economics, University of Punjab.

Iqbal, N. (2010). Driving Banking Forward in Pakistan. Retrieved from http://www.islamicfinancereview.co/wpcontent/uploads/2013/05/02_Driving_Islamic_Ba nking_Forward.pdf

KPMG \& Co. (2014). Banking Survey 2013

Makiyan, S. N. (2010). Risk Management and Challenges in Islamic Banks. Journal of Islamic Economics, Banking and Finance, 2(1). Retrieved from http://ibtra.com/pdf/journal/v4_n3_article3.pdf

Memon, N. A. (2007). Islamic Banking: Present and Future Challenges. Journal of Management and Social Sciences, $3(1)$.

Nassir-Shaari, J. A., Khalique, M. \& Bin Md. Isa, A. H. (2011). Is Ranking of Public and Domestic Private Sector Commercial Banks in Pakistan on the Basis of the Intellectual Capital Performance? KASBIT Business Journal, 4(61-68). Retrieved from http://www.kasbit.edu.pk/KBJVol4/5-M.\%20KhaliqueRanking\%20of\%20Commercial\%20Banks\%20in\%20Pakistan.pdf

Saeed, K. A. (2011). Islamic Banking in Pakistan: A Review of Conventional and Islamic Banking. Proceedings of 2nd International Conference on Business Management. SBP. (2013). Statistics on Scheduled Banks In Pakistan. Statistics \& Data Warehouse Department. Retrieved from www.sbp.org.pk

Sheikh, M. A., Taseen, U., Haider, S. A. \& Naeem, M. (2010). Islamic Vs Conventional Banks in Pakistan (A case study of Bahawalpur). Retrieved from http://www.iub.edu.pk/jer/JOURNAL/BRM_Research_Article.pdf

State Bank of Pakistan. (2013). SBP Financial Stability Review. Retrieved from www.sbp.org.pk

State Bank of Pakistan. (2014). Islamic Banking Bulletin Jan-March 2014. Retrieved from http://www.sbp.org.pk

State Bank of Pakistan. (2014). Third Quarterly Report for the year 2013-14 of the Central Board of State Bank of Pakistan. Retrieved from http://www.sbp.org.pk

State Bank of Pakistan. (2014). Knowledge, Attitude and Practices (KAP Study) of Islamic Banking in Pakistan. State Bank of Pakistan.

Syndicate Group No. 2. (2010). The Rapid Growth of Banking Sector in Pakistan and its Impacts on Revenue Generation. Syndicate Research Paper, Directorate General of Training \& Research Academy (DOT), FBR, Lahore. 